\title{
Application of the Principal Component Analysis to Disclose Factors Influencing on the Composition of Fungal Consortia Deteriorating Remained Fruit Stalks on Sour Cherry Trees
}

\author{
Donát Magyar ${ }^{1}$ and Gyula Oros ${ }^{2}$ \\ ${ }^{1}$ National Institute of Environmental Health, Budapest, \\ ${ }^{2}$ Plant Protection Institute of the Hungariain Academy of Sciences, Budapest,
}

Hungary

\section{Introduction}

The sour cherry production is concentrated in eastern region of Hungary. During last two decades the commercialized yield varied between 42000-90000 metric tonnes. One of the main constraints is the fruit decay (anthracnose) caused by Colletotrichum gloeosporioides (Penz.) Penz. \& Sacc. in Penz. (teleomorph: Glomerella cingulata [Stoneman] Spauld. \& H. Schrenk). This disease has been known for centuries, and in certain orchards yield losses greater than $90 \%$ periodically occurred under epidemic conditions. In last decade, however, the grave infection has evolved in each season that resulted in disastrous yield losses and led to decrease of harvested area at about $25 \%$. Series of control measures were tried out, many of them with success with some degree (Børve \& Stensvand, 2006; Børve et al., 2010), among them a newly developed biocontrol preparation was applied (Oros \& Naár, 2008; Oros et al., 2011). Detailed analysis of weak efficiency of disease control revealed that beside C. gloeosporioides four other anamorphs of Glomerella were present (Table 1), among them C. acutatum (J.H. Simmonds, 1968), - a new pathogen for the region, - became recently dominant. Its strains, tolerant to recently applied fungicides to control the anthracnose, could be isolated of sour cherry orchards that might be the cause of ineffectiveness of control measures in 2006-2010 (Oros et al., 2010). At the increasing costs of cultivation only high yields may secure a profitable production of sour cherry. From this point of view, the anthracnose caused by Glomerella anamorph with special regards to C. acutatum is an important element of uncertainty that means elaboration of efficient control measures is the critical challenge to unconquerable sour cherry production. Efficient control measures reduce the yield loss in the orchard by suppressing the pathogen (i.e. by the reduction of the number of viable spores and infected fruits). On our major surprise, the pathogen can not be isolated of overwintering fruit mummies in industrial plantations of East Hungary contrarily to other sour cherry producing regions. A survey was carried out to disclose the cause of this phenomenon collecting samples of remained fruit stalks of varieties in sour cherry gene bank of East Hungary. The relationships between host (sour cherry variety) and fungi associated to stalks have been analyzed by multivariate methods: Non-linear Mapping 
and Principal Component Analysis (PCA) combined with Potency Mapping (PM) and Spectral Mapping (SPM) techniques.

\begin{tabular}{|l|l|c|c|c|c|c|}
\hline & Location & Cglo & Cacu & Ctru & Ctri & n.d. \\
\hline Újfehértó & $47^{\circ} 46^{\prime} 46.7^{\prime \prime} \mathrm{N}, 21^{\circ} 39^{\prime} 10.2^{\prime \prime} \mathrm{E}$ & + & + & + & - & + \\
\hline Újfehértó & $47^{\circ} 40^{\prime} 22.2^{\prime \prime} \mathrm{N}, 21^{\circ} 41^{\prime} 24.7^{\prime \prime} \mathrm{E}$ & + & + & - & - & - \\
\hline Pilis & $47^{\circ} 15^{\prime} 45.9^{\prime \prime} \mathrm{N}, 19^{\circ} 34^{\prime} 13.1^{\prime \prime} \mathrm{E}$ & + & + & + & + & + \\
\hline Szentendre & $47^{\circ} 44^{\prime} 94.3^{\prime \prime} \mathrm{N}, 19^{\circ} 03^{\prime} 10.7^{\prime \prime} \mathrm{E}$ & + & - & - & - & - \\
\hline Budapest & $47^{\circ} 31^{\prime} 34.3^{\prime \prime} \mathrm{N}, 19^{\circ} 01^{\prime} 44.7^{\prime \prime} \mathrm{E}$ & + & + & - & - & - \\
\hline Budapestb & $47^{\circ} 30^{\prime} 50.8^{\prime \prime} \mathrm{N}, 19^{\circ} 00^{\prime} 38.5^{\prime \prime} \mathrm{E}$ & - & - & - & + & - \\
\hline Érd & $47^{\circ} 24^{\prime} 07.3^{\prime \prime} \mathrm{N}, 18^{\circ} 55^{\prime} 26.1^{\prime \prime} \mathrm{E}$ & - & + & - & - & + \\
Agárd & $47^{\circ} 11^{\prime} 03.8^{\prime \prime} \mathrm{N}, 18^{\circ} 35^{\prime} 15.1^{\prime \prime} \mathrm{E}$ & + & + & - & - & + \\
\hline Szombathelyc & $47^{\circ} 13^{\prime} 51.3^{\prime \prime} \mathrm{N}, 16^{\circ} 33^{\prime} 33.8^{\prime \prime} \mathrm{E}$ & - & + & - & - & + \\
\hline Jakabszállás & $47^{\circ} 45^{\prime} 16.3^{\prime \prime} \mathrm{N}, 14^{\circ} 37^{\prime} 24.4^{\prime \prime} \mathrm{E}$ & + & + & - & - & - \\
\hline Kecskemét & $46^{\circ} 53^{\prime} 45.9^{\prime \prime} \mathrm{N}, 19^{\circ} 42^{\prime} 24.8^{\prime \prime} \mathrm{E}$ & + & + & - & - & - \\
\hline Jakabszállás & $46^{\circ} 29^{\prime} 28.7^{\prime \prime} \mathrm{N}, 19^{\circ} 16^{\prime} 22.7^{\prime \prime} \mathrm{E}$ & + & + & - & - & - \\
\hline
\end{tabular}

Table 1. Presence of Colletotrichum (Corda) species related to sour cherry in various regions of Hungarya.

\footnotetext{
a=Isolates of each species gangrene the fruits of sour cherry (Prunus cerasus L. cv. Kántorjánosi), $\mathrm{b}=$ collected of Hedera helix L., $\mathrm{c}=$ herbarium specimen of Fallopia sachalinensis (F. Schmidt) Ronse Decr.; Cglo=C. gloeosporioides (Penz.) Penz. \& Sacc. (Glomerella cingulata (Stoneman) Spauld. \& H. Schrenk); Cac $=$ C. acutatum J.H. Simmonds (G. acutata Guerber \& J.C. Correll), Ctrun=C. truncatum (Schwein.) Andrus \& Moore (G. truncata C.L. Armstr. \& Banniza), Ctri=C. trichellum (Fr.) Duke; n.d.=unidentified.
}

Various multivariate mathematical-statistical methods have been widely applied to elucidate the relationship between the columns and rows of any data matrix. In general, the choice of a particular multivariate method for data analysis is dictated by the properties of the data and by the objectives. The PCA, introduced by Pearson (1901), is a useful and widely applied technique to reduce the number of multidimensional contrasts and to reproduce the original data in low dimensional space. In this perspective PCA is a versatile and an easily applicable multivariate method, which forms clusters of variables and observations taking into consideration simultaneously the overall effect of factors under investigation without being one of dependent variable (Mardia et al., 1979). In last four decades over 43000 scientific papers were published that applied PCA for data analysis among them more than 800 intensively reviewed them (Fig 1). There are large literatures in diverse areas such as psychometrics, chemometrics, computer science and ecology applying PCA. Biological and environmental sciences are among the top users. Such statistic is widely used in these works to determine the source of a variety of soil, plant and atmospheric contaminants, e.g. heavy metals (Titseesang et al., 2008; Schwarz et al., 1999; Tokalioglu et al ., 2010), trace metals (Rungratanaubon et al., 2008; Shaheen et al., 2005; Shah et al., 2006; Vasconcellos et al., 2007), PM 2.5 and PM10 particles (Jacquemin et al., 2009; Quraishi et al., 2009) and volatile organic compounds (You et al., 2008). 
Especially in agricultural sciences, where complex datasets with biotical and abiotic variables are often used, the application of multivariate statistics is fundamental. In these studies, PCA is mostly applied to reduce the number of input variables (Uno et al., 2005). Also, these calculations are used to develop precision agriculture applications using crop monitoring (Yang et al., 2004), to uncover gradients of canopy structure (Frazer et al., 2005), to determine the time of harvest (Garcia-Mozo et al., 2007) or to evaluate sampling methods (Magyar et al., 2011). Although, in particular, atmospheric science is a rich source of both applications and methodological developments that influenced applications of PCA. In the field of aerobiology relatively few papers have been published. PCA was applied to analyze the variability of fruit production based on aerobiological pollen data (Ribeiro et al., 2007, 2008), as well as to connect meteorological parameters with the periods of high pollen concentrations (Parrado et al., 2009). This method proved to be reliable to identify the sources and dispersal patterns of airborne bacteria (Lighthart et al., 2009) and spores of plant pathogenic fungi (Frank et al., 2008; Magyar, 1998) that resulted the stressing of its possible use for both signalization of occurrence and identification of sources of plant pathogens. The latter is important in relation to successful control measures in the agricultural areas as the knowledge on the type of dispersal of the pathogen (and biocontrol agent if applied) and the composition of fungal consortia on the target area is crucial for an effective pest control (Magyar 2007).

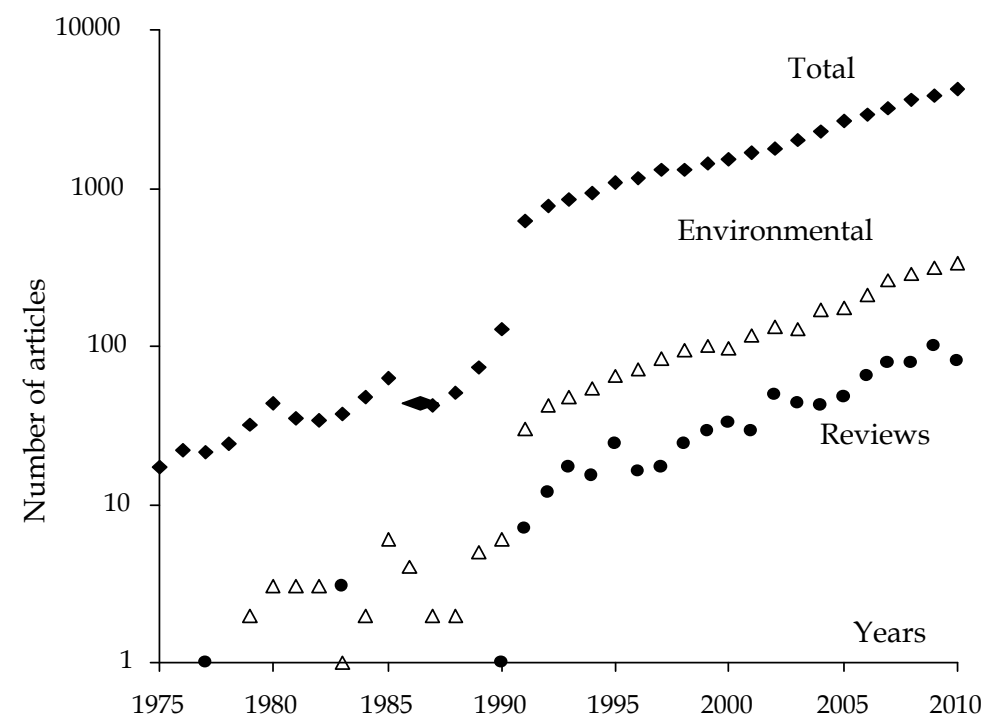

Fig. 1. Changes in abundance of scientific publications that have applied Princpal Component Analysis. Source: Thompson Data Base

The PCA is an exploratory tool to investigate patterns in the data. Usually, the first Principal Component (PC) is accepted to comprise the summarized quantitative aspects of multifactorial effects as the arithmetic mean values of observations correlate with first PC, while the remaining PCs are considered to relate to spectrum of effects. However, the quantitative moments of PC variables are distributed within hidden factors, thus PCA 
cannot be employed when the separation of the strength and selectivity of the effect is required. The spectral mapping technique (SPM) was developed to overcome this difficulty (Lewi, 2005). Using the normalized original data this method divides the information into two matrices. The first one is a vector containing so-called potency values (PV) proportional to the overall effect of factors or the response of organism to them (quantitative measure of the effect). The second matrix (selectivity or spectral map) contains the information related to the variation in manifestation (spectrum) of the effect (qualitative characteristics of the effect). In our case PV relates to the overall abundance of each fungal species noticed on stalks, i.e., it is a quantitative measure of the diversity of fungal consortium, while the spectral map (SM) comprises qualitative characteristics of variety dependent distribution of species in the orchard. The matrices of PC loadings and variables as well as the SM are generally multidimensional. As the human brain is not suitable for the evaluation of the distribution of data in multidimensional space a nonlinear mapping technique (NLMAP) was developed for the reduction of the dimensionality of such matrices (Sammon, 1969).

Our objectives of this study were to evaluate diversity of mycobiota associated to stalks of sour cherry remained on trees, and in this paper we show the use of PCA in conjunction with SPM and NL-Mapping to reveal patterns in distribution of detected fungal species.

\section{Experimental}

\subsection{Location and method of sampling}

2.1.1 Sour cherry fruits were collected in ten different locations (Table 1) of Hungary in period of fruit ripening during 2006-2010 and searched for Colletotrichum acervuli immediately after taking them into the laboratory. The Colletotrichum species are anamorphs of some Glomerella (Ascomycota) fungi and their presence was proved microscopically by usual manner. Of the same locations twig s with 15-25 buds and mummies with stalks were collected in February of subsequent years.

2.1.2 The sour cherry gene bank is located in Újfehértó (East Hungary, $47^{\circ} 46^{\prime} 46^{\prime \prime} \mathrm{N}$, $\left.21^{\circ} 39^{\prime} 10^{\prime \prime} \mathrm{E}\right)$, and it is surrounded by big sized industrial plantations that comprise mainly three varieties (Prunus cerasus L. cv. Érdi bőtermő, Kántorjánosi and Újfehértói fürtös). The up to date management practices have usually been carried out in the area. On the nearby two plots (4 ha size of each) Trichoderma-based biopreparations (Oros and Naár, 2008) were applied during past three vegetation periods (Oros et al., 2010, 2011). Fruit stalks remained on trees were collected in March 2011 (10 samples of each tree and 10-30 stalks per sample) of 18 varieties of gene bank as well as of trees of the two industrial plots and kept in freezer up to analysis.

\subsection{Survey of fungal population on stalks}

2.2.1 The twigs collected in diverse areas in first week of February (2.1.1.) were plug in pots filled with wetted perlite and tucked into plastic bag for 48 hours at ambient temperature to promote acervuli formation on surface of tissues infected with Colletotrichum. The acervulus is a characteristic reproductive organ of Glomerella anamorphs that easy to recognize of dark brown, thorn like, prominent setae examining samples under dissecting microscope. 


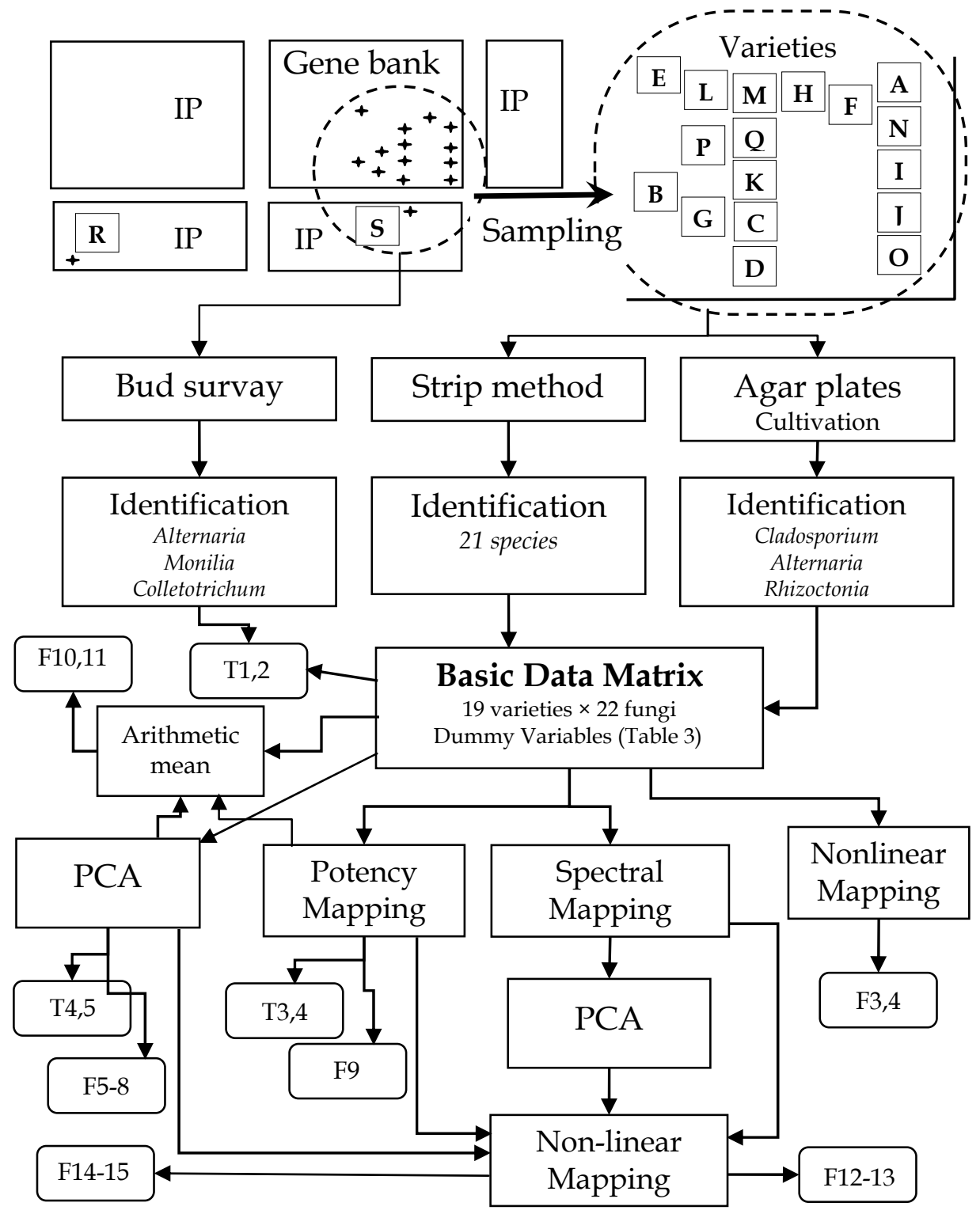

Fig. 2. Flow diagram of the experimental protocol.

$\mathrm{IP}=$ industrial plantation. The capital letter codes of varieties are given in Table 2.

The labels in ellipses $(\mathrm{T} 1,2 . . \mathrm{n})$ and $(\mathrm{F} 1,2 . . \mathrm{n})$ mark number of tables and figures in body text where the results of computation was used for demonstration.

2.2.2 Stalks collected of trees in winter were placed on the surface of Czapek Agar plates amended with antibiotics (ampicillin, kanamycin and streptomycin) to supress bacteria. The 
growth of fungi on the surface of stalks as well as on the agar plates had been survayed daily during three weeks.

2.2.3 To study the fungal spectra of the fruit stalks, a microscopic method was applied which was developed to enable in situ investigations by the use of pressure sensitive acrylic strips (MACbond B 1200, MACtac Europe S.A., Brussels). The strip consists of a thin $(20 \mu \mathrm{m})$ polypropylene film coated on both sides with a rubber based adhesive, which offers very high adhesion property on the stalks. The tape is viewed directly under a microscope to identify the fungi present on the sampled surface under $\times 800$ magnification.

All mycological work was done applying usual manners widely accepted in microbiology. Spores have been grouped into hydrophobic dry spores (xerospores) and readily wettable slime spores (gloiospores) (Mason, 1937, Magyar, 2007).

\subsection{Data treatment}

The basic data matrix consisted of the dummy variables that comprise presence (1) or absence $(0)$ of fungal species $(n=22)$ on the stalks of the sour cherry variety $(n=19)$ concerned, which strongly limits the use of data transformation procedures. The yeast species, which occurred on each stalk examined, had been excluded of further data analyses, because PCA and SPM can be employed for the analysis of data matrices which contain variables showing variance. First the Nonlinear Mapping (NLMAP) was applied for clustering both sour cherry varieties and fungi detected on stalks following Sammon (1969).

PCA was carried out on the correlation matrix and only the components having an eigenvalue greater than one were included in the evaluation of data. To facilitate the evaluation of the multidimensional maps of principal component (PC) loadings, their dimensionality was reduced to two by the NLMAP technique.

Potency and Spectral Mapping techniques (Lewi, 2005) were applied on the matrix used for PCA, and applied in order to calculate the abundance and the variety dependent distribution of fungal species as well as the degree of diversity and the heterogeneity spectrum of settlement on proper cherry variety. Potency and Spectral Mapping were carried out twice: (a) The abundance of 19 fungal species represented the variables and the 19 sour cherry variables the observations (spectral map calculated comprises the heterogeneity spectrum of fungal settlement on varieties). (b) The cherry varieties represented the variables and the abundance of 19 fungal species the observations (spectral map calculated comprises the variety dependent distribution of fungi). The potency values calculated relate to either the abundance of fungal species in sour cherry plantation or the degree of diversity of fungal consortium found on stalks of proper variety. The dimensionality of the maps was reduced to two by the NLMAP technique or hidden variables were extracted by PCA as the evaluation of the multidimensional selectivity (spectral) maps of varieties and associated fungi is difficult.

Statistical functions of Microsoft Office Excel 2003 (Microsoft, Redmondton, USA) and Statistica5 program (StatSoft, Tusla, USA) were used for analysis of data. The graphical presentation of result of data analysis was edited uniformly in MSOffice Power Point 2003. 
Sour cherry varieties

No. Codea Gene bank

1 A

2 B

3 C

4 D

5 E

$6 \quad \mathrm{~F}$

$7 \quad$ G

$8 \mathrm{H}$

9 I

$10 \mathrm{~J}$

$11 \mathrm{~K}$

12

$13 \mathrm{M}$

$14 \mathrm{~N}$

$15 \mathrm{O}$

$16 \mathrm{P}$

$17 \mathrm{Q}$

Industrial plantation ${ }^{b}$

18 R KántorjánosiU

19 S KántorjánosiH

Szomolyai
Fungal species detected on stalk remained on trees

No. Code Taxonomic position ${ }^{\mathrm{c}}$ and scientific name

Ascomycota

Pezizomycotina

1 tol Trullula olivascens (Sacc.) Sacc.

Dothideomycetes, Botryosphaeriales

2 dte Diplodia tecta var. cerasii Berk. \& Broome

Dothideomycetes, Capnodiales

3 cla Cladosporium sp.

Dothideomycetes, Pleosporales

4 agl Aglaospora profusa (Fr.) De Not.g

5 alt Alternariasp.

6 ppo Phoma pomorum Thüm.

7 epu Epicoccum purpurascens Ehrenb.

8 lep Leptosphaeriasp.

9 phe Pleospora herbarum P. Karst.

\begin{tabular}{rr|l} 
Pándy 56 & 9 & phe Pleospora herbar \\
Sylvana & 10 & ple
\end{tabular}

11 sfo

Splanchnonema foedans (Fr.) Kuntzeg

Vanda

12 ste

Stemphylium sp.

Sordariomycetes ${ }^{c}$

13 sor unidentified sp. ${ }^{\mathrm{d}}$

Sordariomycetes, Glomerellalese

14 cgl Colletotrichum gloeosporioides (Penz.) Penz. \& Sacc.

Sordariomycetes, Xylariales

$15 \mathrm{dpl}$ Dendrophoma pleurospora (Sacc.) Sacc.

Sordariomycetes, Diaporthales

16 cyt Cytosporasp.

Pezizomycotina, Helotiales

17 mon Moniliasp.

18 m-s Steril mycelium ${ }^{\mathrm{f}}$

$19 \mathrm{y}-\mathrm{w}$ yeast 1 - white

20 y-r yeast 2 - red

21 y-b yeast 3 - black

Basidiomycota

Agaricomycetes, Cantharellales

22 rhi Rhizoctonia sp.

Table 2. Stalk samples collected in gene bank of Újfehértó and the list of detectable fungi associated to.

$a=$ The codes of sour cherry varieties (capital letters) and fungal species colonized them during the winter are used in following tables and figures. $b=$ These plantations are adjacent to the gene bank. $c=$ Species were assigned according to Index Fungorum. $\mathrm{d}=$ Detected only on a single stalk, $\mathrm{e}=$ Immature perithecia, $\mathrm{f}=$ Mycelium of an ascomycetaceous fungal species, $\mathrm{g}=$ free spores. 


\section{Results}

3.1 The presence of Colletotrichum species was in each location stated on ripening fruits during vegetation periods of 2006-2010, and among them C. acutatum proved to be dominant being followed by C. gloeosporioides (Table 1). The occurrence of other Glomerella anamorphs was sporadic. In several samples acervuli of a Colletotrichum species unknown for Hungarian mycoflora were observed. Neither on leaves collected during vegetation period nor on decaying fruits were found Glomerella perithecia (sexual reproductive organ) in 2006-2011. The yield losses caused by anthracnose were significant in each location. The role of other pathogenic fungi was insignificant, among them Monilia sp. was most frequent, although in few cases P. pomorum, D. tecta and Gibberella avenacea R.J. Cook associated also to fungal consortium. The sporadic appearance of other than Colletotrichum fungal species was seemingly connected to intensive pest management in sour cherry plantations.

3.2 On twigs collected in February of 2007-2011 the rate of infection varied between 2 and 90 percents (method 2.2.1). C. acutatum, C. gloeosporioides and C. trichellum could be detected (Table 1) in listed order, but the samples of Újfehértó where C. gloeosporioides was only found. In the gene bank (L-1) the manifested infection rate on the twig s was low, moreover, few infected buds could be found only on two varieties (P. cerasus L. cv. Érdi bőtermő and Újfehértói fürtös). Also, C. gloeosporioides was the single overwintering Colletotrichum in Central Hungary (L-4), although in this orchard acervuli of other Glomerella anamorphs were not discovered on decayed fruits in vegetation period. C. trichellum was detected in one orchard only (L-3) on fruits, and in the same place it was found on basal parts of stalks. C. truncatum was found only on fruits in two locations (L1 and L3) suggesting that this species does not overwinter on sour cherry trees. Other fungal species were detected such as Alternaria spp., Cytospora sp. and Phoma pomorum.

3.3 Counteracting to special analysis cosmopolite fungi Alternaria and Cladosporium overgrew rapidly all others on stalks placed on the Czapek Agar plates (method 2.2.2) except Rhizoctonia solani J.G. Kühn (teleomorph: Thanatephorus cucumeris [A.B. Frank] Donk) that was identified of two varieties (Pándy 56 of gene bank and Kántorjánosi of industrial plantation). The Trichoderma strains of biopreparate were not detectable. The acervulus of C. gloeosporioides could be detected on a single stalk (variety Aranka of gene bank).

3.4 Following protocol 2.2.3. we could detect presence of 8 known phytopathogenic and 13 saprobiont fungal species in samples collected in gene bank of Újfehértó (Table 2). Five species occurred only in a single variety (Table 3). Thus, intensively growing sterile mycelium of an ascomycete was observed on stalks of Debreceni bőtermó (N, letter codes of varieties are given in Table 2); however, this did not counteract the detection of other fungal species. Also, immature perithecia could be seen on stalks of Géczi (E). Spores of three phytopathogenic species causing branch dieback, Leptosphaeria, Splanchonema and Cytospora were detected on stalks of varieties $\mathrm{B}, \mathrm{P}$ and $\mathrm{R}$, respectively. The most frequent Alternaria and Stemphylium being facultatively parasitic can take part in fruit decay. The occurrence of Monilia, one of the most devastating pathogens of sour cherry, was less pronounced as expected. The other species are known as saprobionts and we have no information about their possible phytopathogenic properties, nevertheless, these can also have importance in postharvesting fruit rot. Presence of none of Glomerella anamorph but C. gloeosporioides on some stalks of a single variety (A) could be detected. 


\begin{tabular}{|c|c|c|c|c|c|c|c|c|c|c|c|c|c|c|c|c|c|c|c|c|}
\hline \multirow{2}{*}{$\begin{array}{l}\text { Fungia } \\
\text { Code }\end{array}$} & \multicolumn{19}{|c|}{ Sour cherry varieties ${ }^{a}$} & \multirow[b]{2}{*}{$\mathrm{PVb}$} \\
\hline & A & B & C & D & $\mathrm{E}$ & $\mathrm{F}$ & G & $\mathrm{H}$ & I & $\mathrm{J}$ & K & $\mathrm{L}$ & M & $\mathrm{N}$ & $\mathrm{O}$ & $\mathrm{P}$ & Q & $\mathrm{R}$ & $S$ & \\
\hline tol & 0 & 0 & 1 & 0 & 0 & 1 & 0 & 1 & 1 & 0 & 0 & 1 & 1 & 1 & 1 & 1 & 0 & 0 & 1 & 52.6 \\
\hline dte & 0 & 0 & 0 & 0 & 0 & 0 & 0 & 0 & 0 & 0 & 0 & 0 & 0 & 1 & 1 & 0 & 0 & 0 & 0 & 10.5 \\
\hline cla & 1 & 0 & 0 & 0 & 1 & 0 & 0 & 0 & 0 & 0 & 0 & 0 & 0 & 0 & 1 & 0 & 1 & 0 & 1 & 26.3 \\
\hline agl & 0 & 0 & 1 & 0 & 0 & 0 & 0 & 1 & 0 & 0 & 0 & 0 & 0 & 0 & 0 & 0 & 0 & 1 & 1 & 21.1 \\
\hline alt & 1 & 1 & 1 & 0 & 1 & 1 & 1 & 1 & 1 & 1 & 1 & 1 & 1 & 1 & 1 & 1 & 1 & 1 & 1 & 94.7 \\
\hline ppo & 0 & 0 & 1 & 0 & 0 & 1 & 0 & 0 & 0 & 0 & 0 & 0 & 0 & 1 & 1 & 0 & 0 & 0 & 0 & 21.1 \\
\hline epu & 0 & 0 & 0 & 0 & 0 & 0 & 0 & 0 & 0 & 0 & 0 & 0 & 0 & 0 & 1 & 1 & 1 & 0 & 0 & 15.8 \\
\hline lep & 0 & 1 & 0 & 0 & 0 & 0 & 0 & 0 & 0 & 0 & 0 & 0 & 0 & 0 & 0 & 0 & 0 & 0 & 0 & 5.3 \\
\hline phe & 1 & 0 & 0 & 1 & 1 & 0 & 0 & 0 & 0 & 0 & 1 & 0 & 0 & 0 & 1 & 0 & 0 & 1 & 0 & 31.6 \\
\hline ple & 0 & 0 & 0 & 0 & 1 & 0 & 0 & 0 & 0 & 0 & 0 & 0 & 0 & 0 & 0 & 1 & 0 & 0 & 0 & 10.5 \\
\hline sfo & 0 & 0 & 0 & 0 & 0 & 0 & 0 & 0 & 0 & 0 & 0 & 0 & 0 & 0 & 0 & 1 & 0 & 0 & 0 & 5.3 \\
\hline ste & 1 & 0 & 0 & 1 & 1 & 0 & 0 & 0 & 1 & 1 & 1 & 0 & 0 & 1 & 1 & 1 & 1 & 0 & 0 & 52.6 \\
\hline sor & 0 & 0 & 0 & 0 & 0 & 0 & 1 & 0 & 0 & 0 & 0 & 0 & 0 & 0 & 0 & 0 & 0 & 0 & 0 & 5.3 \\
\hline cgl & 1 & 0 & 0 & 0 & 0 & 0 & 0 & 0 & 0 & 0 & 0 & 0 & 0 & 0 & 0 & 0 & 0 & 0 & 0 & 5.3 \\
\hline $\mathrm{dpl}$ & 0 & 0 & 1 & 0 & 0 & 0 & 0 & 0 & 0 & 0 & 1 & 0 & 0 & 0 & 1 & 0 & 1 & 0 & 0 & 21.1 \\
\hline cyt & 0 & 0 & 0 & 0 & 0 & 0 & 0 & 0 & 0 & 0 & 0 & 0 & 0 & 0 & 0 & 0 & 0 & 1 & 0 & 5.3 \\
\hline mon & 0 & 1 & 0 & 0 & 0 & 0 & 1 & 0 & 0 & 0 & 0 & 0 & 0 & 1 & 0 & 0 & 0 & 0 & 1 & 21.1 \\
\hline $\mathrm{ms}$ & 0 & 0 & 0 & 0 & 1 & 0 & 0 & 0 & 0 & 0 & 0 & 0 & 0 & 0 & 0 & 0 & 0 & 0 & 0 & 5.3 \\
\hline y1 & 1 & 1 & 1 & 1 & 1 & 1 & 1 & 1 & 1 & 1 & 1 & 1 & 1 & 1 & 1 & 1 & 1 & 1 & 1 & 100 \\
\hline y2 & 1 & 1 & 1 & 1 & 1 & 1 & 1 & 1 & 1 & 1 & 1 & 1 & 1 & 1 & 1 & 1 & 1 & 1 & 1 & 100 \\
\hline y3 & 1 & 1 & 1 & 1 & 1 & 1 & 1 & 1 & 1 & 1 & 1 & 1 & 1 & 1 & 1 & 1 & 1 & 1 & 1 & 100 \\
\hline rhi & 0 & 0 & 0 & 0 & 0 & 0 & 0 & 0 & 0 & 0 & 0 & 0 & 0 & 1 & 0 & 0 & 0 & 0 & 1 & 10.5 \\
\hline
\end{tabular}

Table 3. Mycological analysis of stalks collected in gene bank of Ujfehértó.

$a=$ codes of fungi and varieties are shown in Table 2. $b=$ Potency Values as percent of the maximum abundance. $0=$ not found, $1=$ presented on more than 1 specimen.

\subsection{Data analysis}

\subsubsection{Non-linear mapping}

Both sour cherry varieties and associated fungal species were mapped following method of Sammon (1969). The fungi might be grouped by their relation to host plant, one of clusters comprise pathogens (dotted line) while the other the saprobionts mainly (Fig 3).

In the case of varieties no clusters could be recognized (Fig 4). The four varieties (E, F, S and R) are near relatives, and their position on NLMap is not linked. These were selected for free pollination and improving the mechanic harvest. Unfortunately, data on the genetic background of other varieties is absent; the varieties $\mathrm{B}, \mathrm{O}$ and $\mathrm{Q}$ were introduced of other geographic regions. The varieties $\mathrm{F}, \mathrm{R}, \mathrm{S}$ and $\mathrm{E}$ are extremely susceptible to anthracnose caused by $C$. acutatum in decreasing order; moreover their susceptibility to Monilia is outstanding too. Nevertheless, due to the high commercial value of their fruits and favorable biological properties these are the most run varieties in Hungary. 


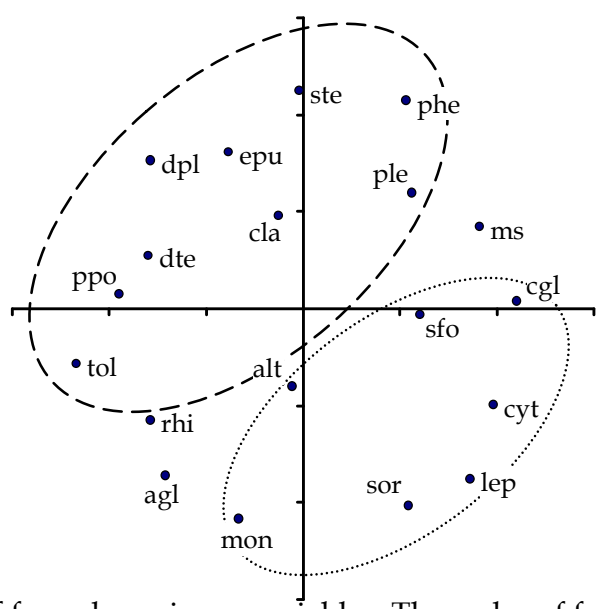

Fig. 3. Non-linear Map of fungal species as variables. The codes of fungi are given in Table 3. Ellipses with dotted and broken lines mark groups of pathogenic and saprotrophic fungi, resp.

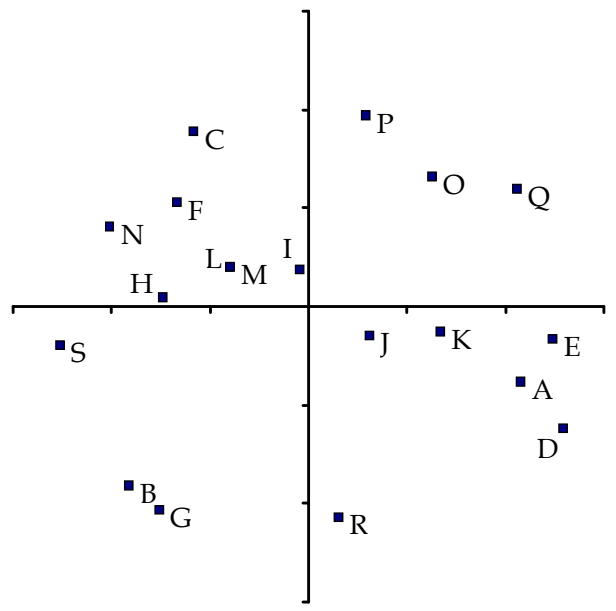

Fig. 4. Non-linear Map of sour cherry varieties as variables. The codes of varieties as given in Table 3.

\subsubsection{Principal Component Analysis}

\subsubsection{Influence of sour cherry varieties on distribution of associated fungi}

The PC loadings (sour cherry varieties as variables) computed by PCA are compiled in Table 4. Five hypothetical (background) variables explained the majority of total variance with $22.57 \%$ loss of information. This fact suggests that the 19 original variables can be reduced to 5 theoretical variables. Most of varieties have high loadings in the first two PCs, and those being in gene bank are positively related, that means these two factors act 
similarly on distribution of associated fungi when deteriorating stalks of varieties concerned. The two sampling points of industrial plantations ( $R$ and $S$ ) have not common weight with the former group.

On bivariate plot of varieties as PC variables no connection can be observed similarly to NLmap (Fig 4), though these two plots are different. The distribution fungal species plotted as PC scores does not show connection between them, although the xerospore producing anemophilous species seem to deviate of the main group comprising gloeospore producing ones.

\begin{tabular}{|c|c|c|c|c|c|c|c|c|}
\hline \multirow[b]{2}{*}{ No. } & \multirow{2}{*}{$\begin{array}{c}\text { Variables } \\
\text { Sour cherry varieties }\end{array}$} & \multirow[b]{2}{*}{ Code } & \multicolumn{5}{|c|}{ Principal components } & \multirow{2}{*}{ PVa } \\
\hline & & & PC1 & PC2 & PC3 & PC4 & PC5 & \\
\hline 1 & Aranka & A & 0.44 & 0.65 & -0.22 & 0.14 & 0.01 & 36.4 \\
\hline 2 & Bigarreau & B & 0.34 & -0.23 & -0.69 & -0.25 & 0.15 & 27.3 \\
\hline 3 & Bosnyák & $\mathrm{C}$ & 0.60 & -0.40 & 0.32 & 0.36 & 0.31 & 36.4 \\
\hline 4 & Csengődi & $\mathrm{D}$ & 0.20 & 0.80 & -0.02 & 0.12 & 0.02 & 22.7 \\
\hline 5 & Debreceni bőtermő & $\mathrm{E}$ & 0.35 & 0.64 & -0.18 & 0.07 & -0.29 & 40.9 \\
\hline 6 & Érdi bőtermő & $\mathrm{F}$ & 0.74 & -0.40 & 0.26 & -0.01 & 0.12 & 27.3 \\
\hline 7 & Géczi & G & 0.34 & -0.23 & -0.69 & -0.25 & 0.15 & 27.3 \\
\hline 8 & Germersdorfi & $\mathrm{H}$ & 0.73 & -0.44 & 0.01 & 0.39 & -0.18 & 27.3 \\
\hline 9 & Halka & I & 0.90 & 0.09 & 0.09 & -0.19 & -0.18 & 27.3 \\
\hline 10 & Horka & $\mathrm{J}$ & 0.75 & 0.43 & -0.21 & -0.21 & -0.05 & 22.7 \\
\hline 11 & Katalin & $\mathrm{K}$ & 0.56 & 0.64 & -0.07 & 0.18 & 0.26 & 31.8 \\
\hline 12 & Maliga emléke & $\mathrm{L}$ & 0.88 & -0.35 & 0.06 & 0.01 & -0.19 & 22.7 \\
\hline 13 & Margit & M & 0.88 & -0.35 & 0.06 & 0.01 & -0.19 & 22.7 \\
\hline 14 & Pándy 56 & $\mathrm{~N}$ & 0.56 & -0.20 & 0.04 & -0.44 & 0.35 & 45.5 \\
\hline 15 & Sylvana & $\mathrm{O}$ & 0.56 & 0.35 & 0.49 & -0.02 & 0.42 & 54.5 \\
\hline 16 & Szomolyai & $\mathrm{P}$ & 0.54 & 0.12 & 0.28 & -0.35 & -0.58 & 40.9 \\
\hline 17 & Vanda & Q & 0.47 & 0.49 & 0.12 & -0.16 & 0.21 & 36.4 \\
\hline 18 & Kántorjánosi-U & $\mathrm{R}$ & 0.33 & 0.07 & -0.33 & 0.78 & -0.06 & 31.8 \\
\hline 19 & Kántorjánosi-H & $S$ & 0.49 & -0.44 & -0.28 & 0.10 & 0.08 & 40.9 \\
\hline \multicolumn{3}{|c|}{ Eigenvalues (Explained variation) } & 6.74 & 3.54 & 1.79 & 1.51 & 1.13 & \\
\hline \multicolumn{3}{|c|}{ Proportion total } & 35.5 & 18.6 & 9.4 & 8.0 & 6.06 & \\
\hline
\end{tabular}

Table 4. Principal Component Loadings

$a=$ Potency Values as percent of the maximum abundance.

\subsubsection{Similarities in distribution of fungi on stalks of sour cherry}

Nine hidden (background) variables explained the $87.82 \%$ of total variance, however, altering of the variations in susceptibility of sour cherry none of eigenvalues exceeded $20 \%$. Six variables (fungal species) dominated two PCs, while only three PCs were dominated by more then one variable on bivariate blots by two major PCs neither PC loadings (Fig 7, fungi) nor PC scores (Fig 8, varieties) are designated to explainable clusters, because neither 
taxonomic position nor mode of distribution of fungi could be linked to groups as well as relations of sour cherry varieties with similar genetic background (E, F, R and S) or their spatial position in gene bank could be linked on plot (Fig 8).

On our view the above facts indicate the multifactorial and highly specific character of interaction between sour cherry and associated mycobiota. This aspect seems to be support by formation of two big clusters on Figure 5, since genetic background of the mode of life is very complex and the strategy of infection of these pathogens is also different.

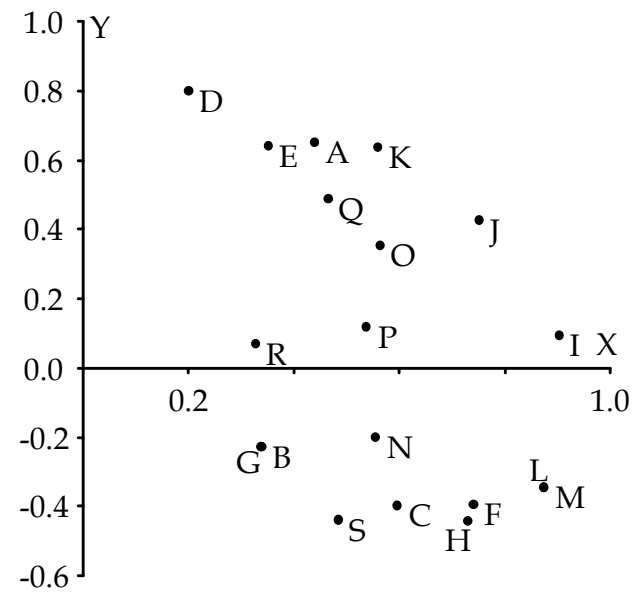

Fig. 5. Plotting sour cherry varieties as PC loadings by two major PCs. The capital letters mark varieties as given in Table 3. The distribution of variables is determined by $54 \%$ of total variation.

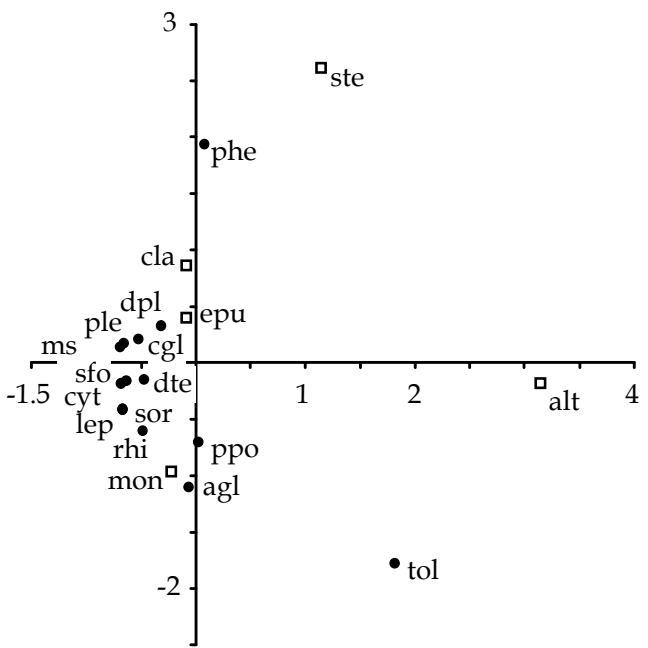

Fig. 6. Plotting fungal species as PC scores by two major PCs. The codes of fungi are given in Table 3. Full circles and opened squares mark species producing xero- or gloeospores, resp. 


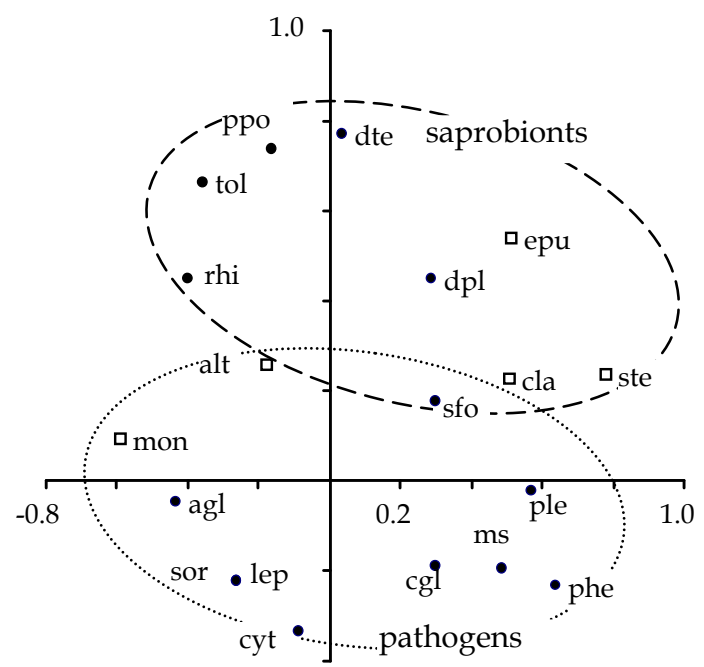

Fig. 7. Plotting fungal species as PC loadings by two major PCs components. The codes of fungi are given in Table 3. Full circles and opened squares mark species producing xero- or gloeospores, resp.

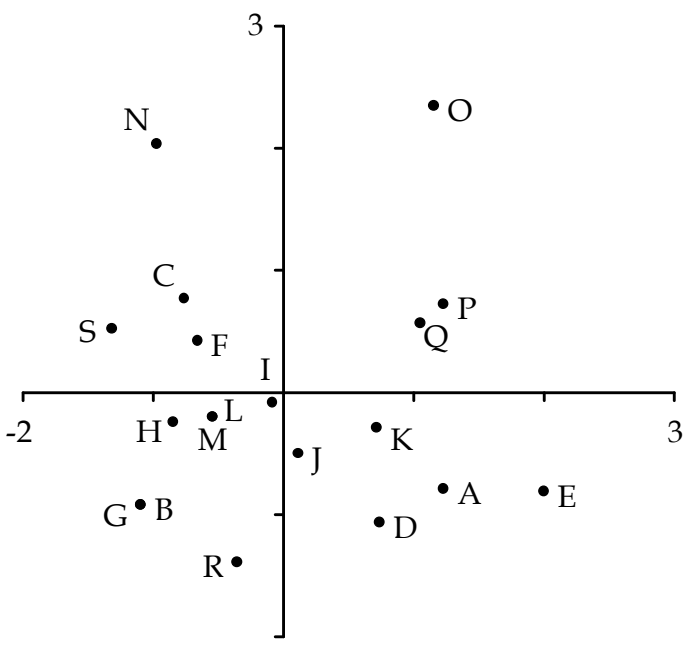

Fig. 8. Plotting sour cherry varieties as PC scores by two major principal components. The capital letters mark varieties as given in Table 3. The distribution of variables is determined by $33 \%$ of total variation.

\subsubsection{Potency mapping}

The potency values (PV-SC) of individual sour cherry varieties and associated fungi calculated by potency mapping technique are included into Tables 4 and 3; all PVs are transformed into percents of the possible maximum for correlation analyses. 
The potential diversity of mycobiota varied between 10-50 percents in gene bank (Fig 9A) that means no one of varieties was colonized with full spectrum of fungi detected in the area. The genetic background has seemingly minor importance in this respect because the PVs of related varieties are different. However, the highest PVs were measured one trees located near the edge of the orchard suggesting the importance of spatial position of trees influences in major extent the diversity of associated mycobiota than the genetic background. The potential incidence of fungal species (PV-FI) varied in higher extent (5-100 \%) than PV-SC (Fig 9 B); being the yeasts the most dispersed fungi. The saprobionts had higher values than phytopathogens in general, although the facultatively parasitic Alternaria was dominant in majority of samples. The xerospore producing fungi were more frequent than the gloeospore-forming ones that can be explained by the season of sampling. Gloeospores, tend to be dispersed by water, e.g. rain splash (rain drops hit spore-filled water film on branches and leaves of trees, aerosolizing spores.) Occasionally, gloeospores are also dispersed by insects. In winter time both treetop and most of insect were absent.
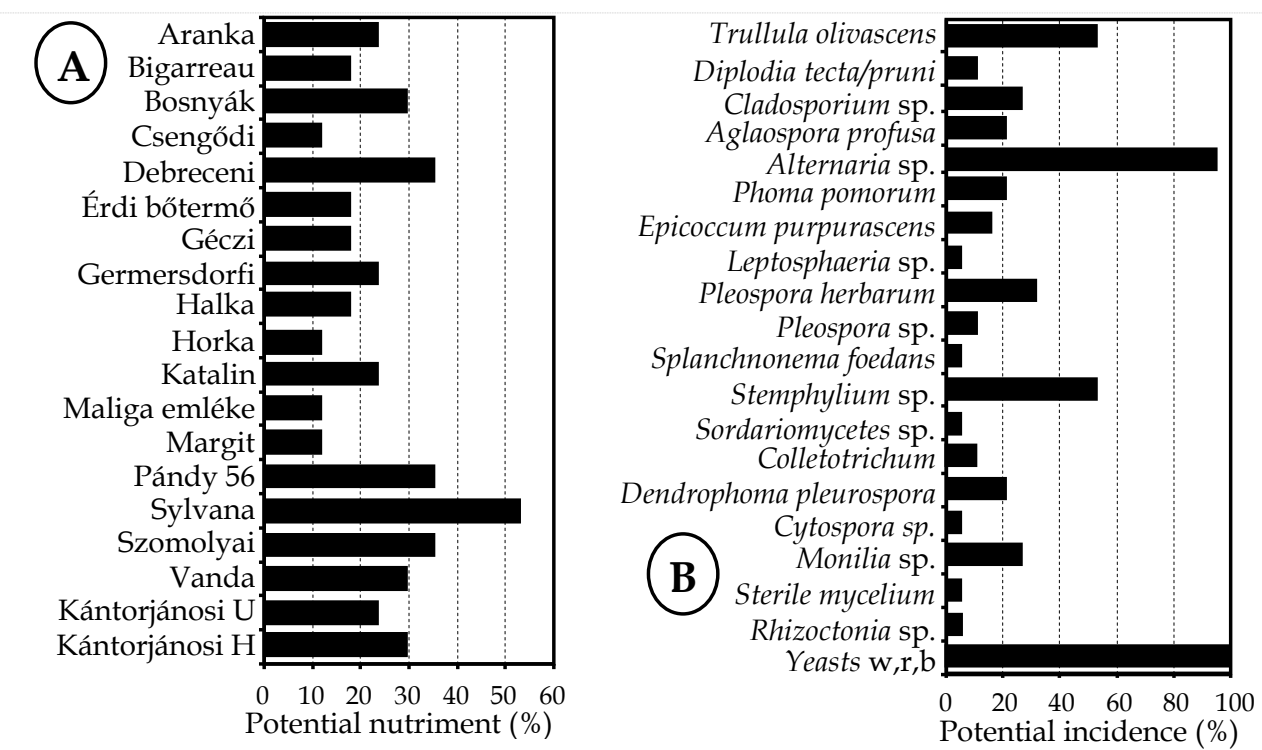

Fig. 9. Potency maps of sour cherry varieties and associated fungal species.

A - diversity of mycobiota associated to stalks takes maximum value in the case when all species detected in gene bank are represented in the sample

B - maximum incidence takes places when the species concerned is presented in all samples.

\subsubsection{Regression analysis}

The arithmetic means of columns and rows (host plant $\times$ fungi), potency values of varieties and fungi, the principal components scores of Tables 4 and 5 were correlated by linear regression analysis (Fig 10 and 11). 


\begin{tabular}{|c|c|c|c|c|c|c|c|c|c|c|c|}
\hline \multicolumn{2}{|c|}{ Variables ${ }^{a}$} & \multicolumn{9}{|c|}{ Principal Components } & \multirow{2}{*}{ Type $^{b}$} \\
\hline No. & Code & PC1 & PC2 & PC3 & PC4 & PC5 & PC6 & PC7 & PC8 & PC9 & \\
\hline 1 & tol & -0.36 & 0.66 & -0.29 & 0.31 & 0.17 & -0.22 & 0.26 & 0.13 & 0.00 & G \\
\hline 2 & dte & 0.03 & 0.77 & 0.30 & -0.26 & 0.00 & -0.15 & -0.27 & -0.12 & 0.00 & G \\
\hline 3 & cla & 0.51 & 0.22 & 0.32 & -0.32 & 0.38 & 0.36 & 0.24 & -0.02 & 0.00 & $x$ \\
\hline 4 & agl & -0.43 & -0.05 & 0.19 & 0.46 & 0.57 & 0.14 & -0.03 & -0.14 & 0.00 & G \\
\hline 5 & alt & -0.18 & 0.26 & -0.18 & 0.01 & 0.31 & 0.64 & 0.23 & 0.13 & 0.00 & $x$ \\
\hline 6 & ppo & -0.16 & 0.74 & 0.26 & 0.10 & -0.02 & -0.10 & -0.15 & 0.22 & 0.00 & G \\
\hline 7 & epu & 0.51 & 0.54 & -0.26 & 0.13 & -0.18 & 0.37 & -0.14 & -0.30 & 0.00 & $x$ \\
\hline 8 & lep & -0.26 & -0.22 & -0.11 & -0.35 & -0.22 & 0.29 & -0.20 & -0.02 & -0.73 & G \\
\hline 9 & phe & 0.64 & -0.23 & 0.55 & 0.02 & 0.16 & -0.12 & -0.24 & -0.13 & 0.00 & G \\
\hline 10 & ple & 0.57 & -0.02 & -0.66 & -0.11 & 0.41 & -0.03 & -0.16 & 0.07 & 0.00 & G \\
\hline 11 & sfo & 0.30 & 0.18 & -0.79 & 0.14 & 0.02 & -0.02 & -0.02 & -0.43 & 0.00 & G \\
\hline 12 & ste & 0.78 & 0.24 & 0.06 & -0.24 & -0.18 & -0.25 & 0.01 & -0.13 & 0.00 & $x$ \\
\hline 13 & sor & -0.26 & -0.22 & -0.11 & -0.35 & -0.22 & 0.29 & -0.20 & -0.02 & 0.73 & G \\
\hline 14 & $\mathrm{cgl}$ & 0.30 & -0.19 & 0.33 & -0.20 & 0.03 & 0.07 & 0.69 & -0.30 & 0.00 & G \\
\hline 15 & $\mathrm{dpl}$ & 0.29 & 0.45 & 0.36 & 0.29 & -0.26 & 0.46 & -0.18 & 0.17 & 0.00 & G \\
\hline 16 & cyt & -0.09 & -0.34 & 0.25 & 0.42 & 0.38 & 0.09 & -0.40 & -0.43 & 0.00 & G \\
\hline 17 & mon & -0.59 & 0.09 & -0.04 & -0.72 & 0.08 & 0.12 & -0.19 & -0.21 & 0.00 & $x$ \\
\hline 18 & $\mathrm{~ms}$ & 0.48 & -0.20 & -0.12 & -0.30 & 0.55 & -0.02 & -0.20 & 0.52 & 0.00 & $\mathrm{u}$ \\
\hline 19 & rhi & -0.40 & 0.45 & 0.11 & -0.44 & 0.43 & -0.26 & 0.03 & -0.25 & 0.00 & $\mathrm{u}$ \\
\hline \multicolumn{2}{|c|}{ Eigenvalue } & 3.38 & 2.83 & 2.18 & 1.95 & 1.66 & 1.32 & 1.19 & 1.12 & 1.06 & \\
\hline \multicolumn{2}{|c|}{ Prop. total } & 17.8 & 14.9 & 11.5 & 10.3 & 8.73 & 6.97 & 6.28 & 5.89 & 5.56 & \\
\hline
\end{tabular}

Table 5. Principal component loadings

$\mathrm{a}=$ Codes are deciphered in Table 2. Yeast species were presented in each sample thus these three variables did not show variance and were omitted of PCA.

$\mathrm{b}=$ Xerospores $(\mathrm{X})$ mostly transported by wind, gloeospores $(\mathrm{G})$ may be transported either by water of animals.

The arithmetic mean on diversity of mycobiota of sour cherry varieties in our case correlated only with potency values $\left(\mathrm{r}^{2}=1\right)$ but no correlation was revealed $\left(\mathrm{r}^{2}=0.12\right)$ with PC scores of first PC and poor correlation $\left(r^{2}=0.49\right)$ with PC scores of PC2 that well demonstrated on Fig 10. Contrarily, the arithmetic mean of dispersal significantly correlated both with potential incidence of fungal species $\left(\mathrm{r}^{2}=1\right)$ and PC scores of first PC $\left(\mathrm{r}^{2}=0.968\right)$ and the relation with scores of second PC is evidently non-linear (Fig11). This entire well demonstrates that the first PC does not comprise always the majority of quantitative measures of the observations, and it is necessary to check this relationship before using PC1 in further calculations. 


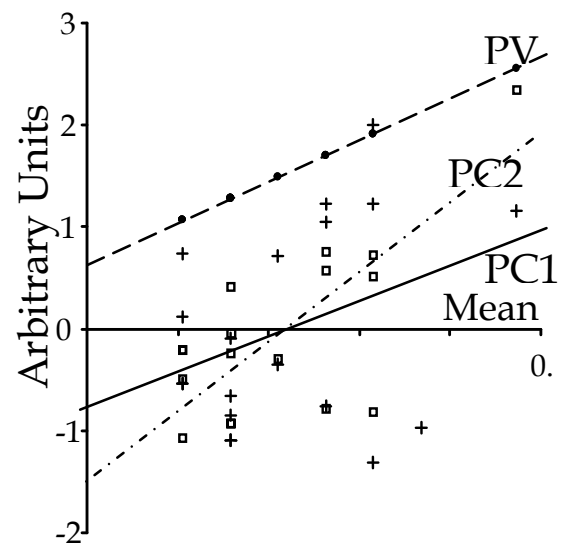

Fig. 10. Relationships between arithmetic mean of diversity of mycobiota and PVs and PC scores of sour cherry varieties.

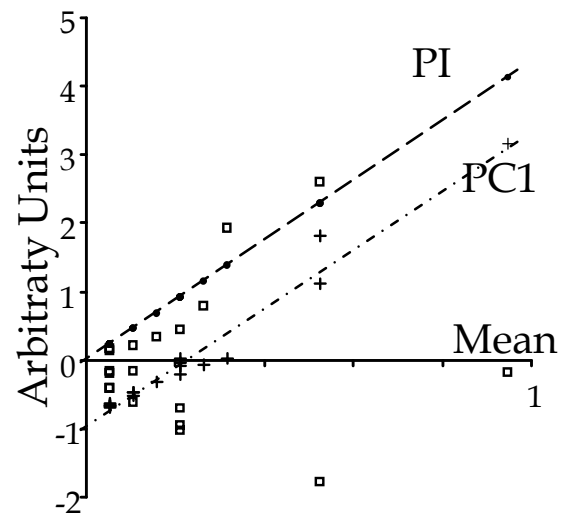

Fig. 11. Relationships between arithmetic mean of incidence of fungal species and PVs and PC scores.

\subsubsection{Spectral component analysis}

The two-dimensional non-linear selectivity map of sour cherry varieties is shown in Figure 12. This map shows similarities to Figure 4. However, in this case there is possible to distinguish a group of varieties where anemophilous fungi dominate the associated fungal consortium deteriorating the remained stalks on trees.

Carrying out the PCA with SPM when varieties serve as variables resulted five significant PC components indicating the elimination of part of total variance of basic data matrix by Potency Mapping. None of them was dominant and on the bivariate plots any patterns could be recognized in grouping of sour cherry varieties (these details are not shown). However, the Non-linear mapping of PC variables revealed three cluster (Fig 13), where varieties seemingly grouped according to composition of the fungal consortia. Moreover, 
this pattern is better pronounced than on Figure 12 supporting the advantage of combination of spectral mapping with PCA as well as the use of NL mapping for studying matrices comprising variables where the setting of observed phenomena influenced by multidunous complex of factors synchronously (environmental, ecological, genetic, etc).

The varietal distribution of fungal species is shown on two-dimensional non-linear selectivity map in Figure 14. The species frequently found on decaying fruits formed a separated cluster, while those parasiting on leaves and phloeme distribute without clear grouping.

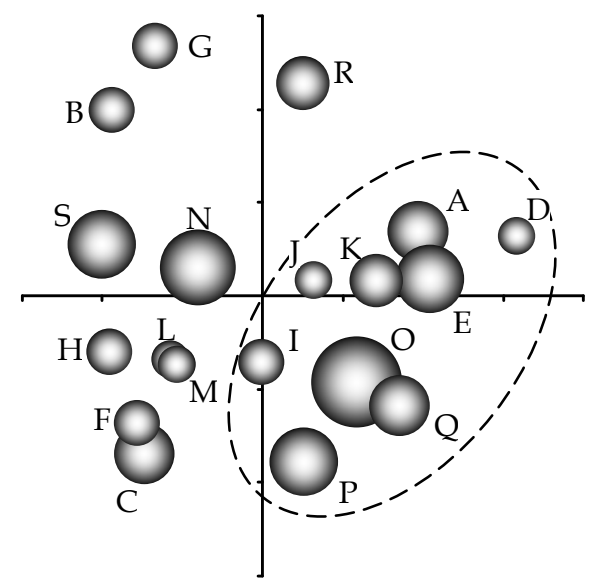

Fig. 12. Non-linear Map of sour cherry varieties as spectral variables. The capital letters mark varieties as given in Table 4 . The size of balls is proportional to potential diversity of mycobiota recorded (Table 4). The ellipse marks the varieties colonized predominantly with xerospore producing fungi.

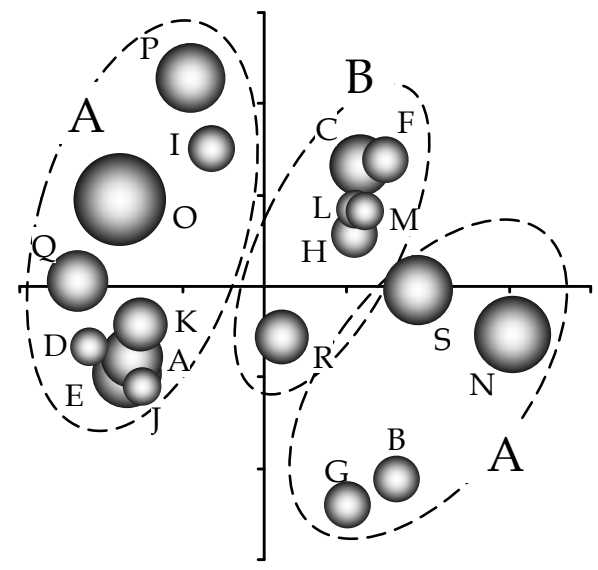

Fig. 13. Similarities in composition of mycobiota on stalk of sour cherry varieties. The capital letters mark varieties as given in Table 4 . The size of balls is proportional to potential diversity of mycobiota recorded (Table 4). The ellipses mark the varieties colonized predominantly with xerospore (A) or gloeospore (B) producing fungi, resp. 


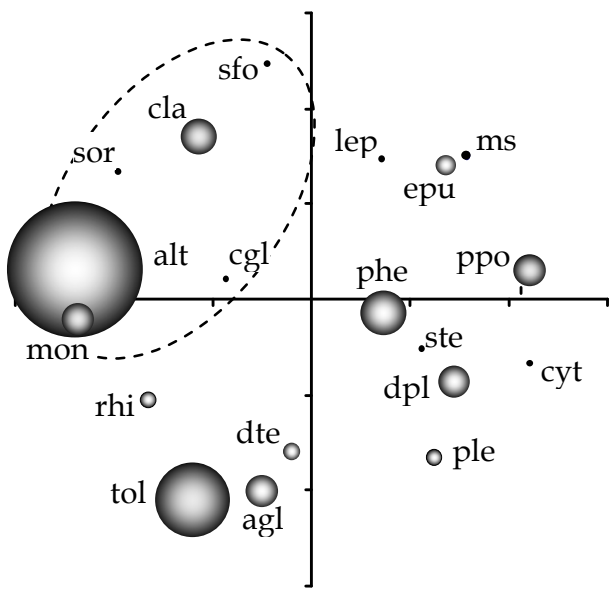

Fig. 14. Non-linear Map of fungal species as spectral variables. The codes of fungi are as given in Table 4. The size of balls is proportional to potential incidence of species recorded (Table 4). The ellipse marks the species causing fruit rot.

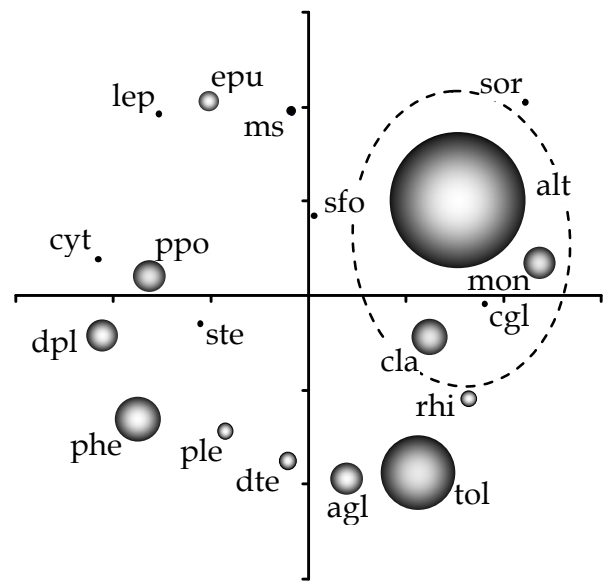

Fig. 15. Similarities in distribution of fungal species on stalk of sour cherry. The codes of fungi are as given in Table 4 . The size of balls is proportional to potential incidence of species recorded (Table 4). The ellipse marks the species causing fruit rot.

The PCA of SC variables resulted eight components with few differences of their eigenvalues. On our opinion this indicates the similar weight of numerous factors influencing on the incidence of fungal species in the orchard. On the NL map of PC variables of SPM the cluster of fruit rotting fungi became more compact. The grouping of the species remained unclear. All this underlines again the value of combined application of spectral mapping with PCA.

Neither sour cherry varieties nor associated fungi formed separated clusters on bivariate NLMaps (graphs are not shown). Most probably the two dimensional mapping distributed 
the information explained by PCs (see Tables 4 and 5) moderately thus the alterations shown by PC loadings were not reflected on scattering of PC scores (varieties or fungi) on the plot, i.e., the two dimensional NL-mapping smashed the variance and divided between two axes. One can frequently meet the clustering of variables on scatter plots and have no success in explanation. Nevertheless, this information is serviceable, because it might orient the further search and design of research project.

However, there were clear groups when tridimensional mapping carried out. In the case of sour cherry (Fig 16) neither the diversity nor the genetic background of varieties channelized the clustering.

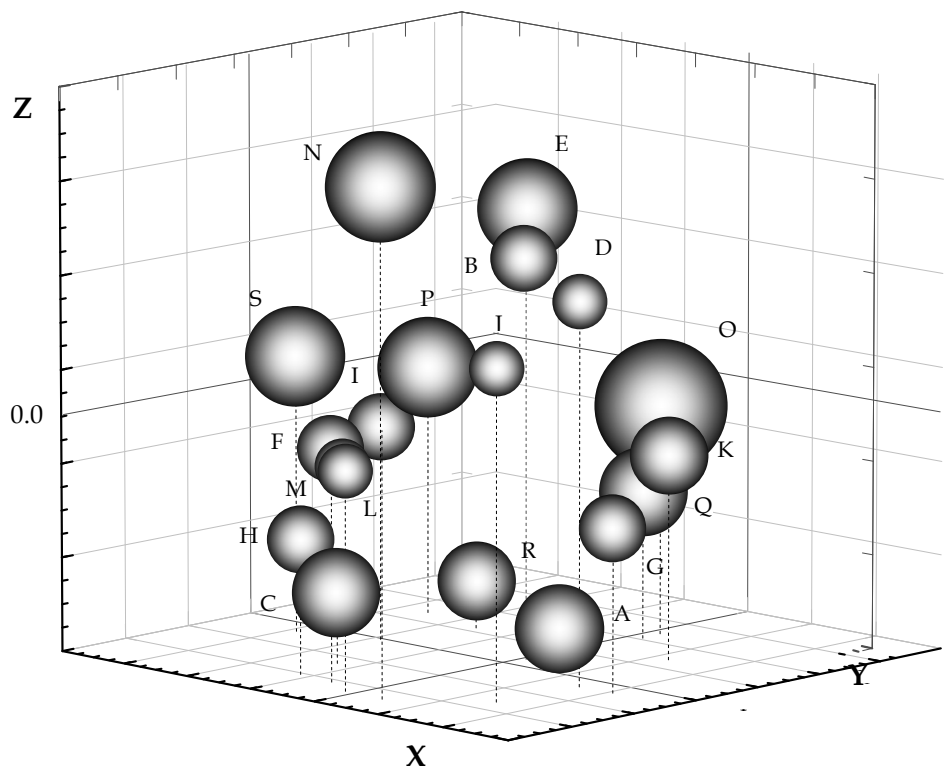

Fig. 16. Non-linear Map of sour cherry varieties as PC scores. The capital letters mark varieties as given in Table 4 . The size of balls is proportional to diversity of colonization recorded (Table 4).

In the case of fungi the separation of species into two groups was more evident (Fig 17). Neither potential incidence nor mode of distribution is seemingly connected to clustering in tridimensional NL map. The first group comprises mainly fungi, which are pathogens or take part in fruit rot both on the tree and post harvesting in stores. Most of saprobionts are in the second groups. There was not found any relationships between taxonomic position of fungal species and their varietal dependent incidence in orchards. The high divergence of the composition of consortia on stalks might cause the absence of Trichoderma strains of biopreparation. 


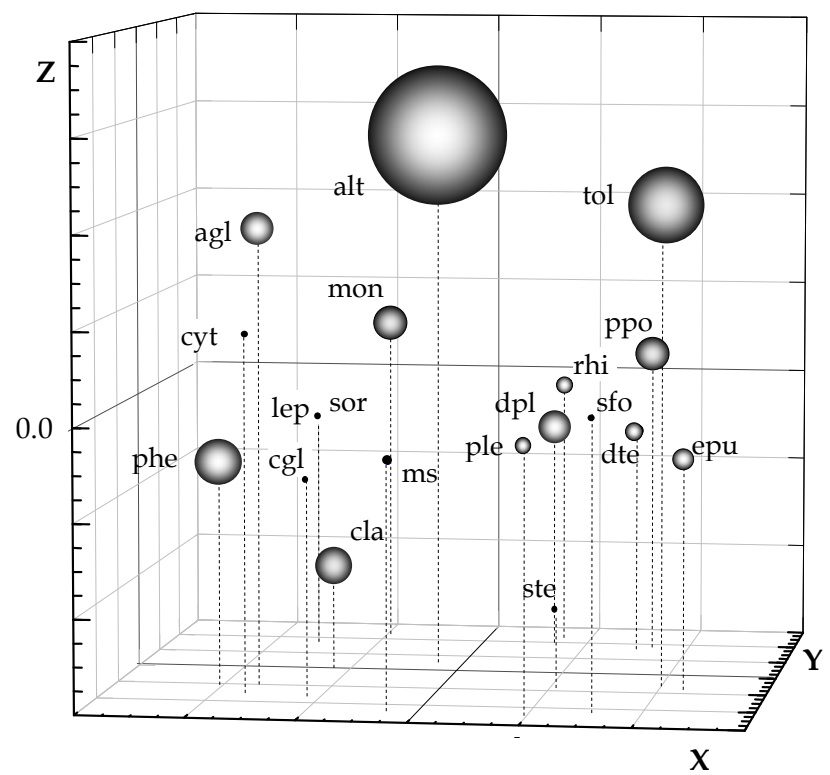

Fig. 17. Non-linear Map of fungal species as PC scores. The codes of fungi are as given in Table 4 . The size of balls is proportional to potential incidence of species recorded (Table 3).

\section{Conclusions}

Presence of five Glomerella anamorphs has been established in Hungarian sour cherry orchards, among them C. acutatum, the new pathogen for Carpathian Basin became dominant over C. gloeosporioides in past five year. Using multivariate statistical methods for detailed analysis of mycobiota revealed two different fungal consortia associated to sour cherry in winter period.

PCA proved to be superior to multidimensional scaling and possible as well as valuable amendment of data exploration when combined with Potency and Spectral Mapping.

The correct order of organization of modules in multivariate analysis of data matrices comprising results of observations or experiments undergone by multifactorial effect can reveal unexpected factors thus increase the profitability of approach.

\section{Acknowledgements}

The research work was supported by the Baross Regional Innovation Programme (No. EA07EA-KOZKFI-2008-0066). We thanks to Á. Szécsi for the critical reading of the manuscript.

\section{References}

Børve, J. \& Stensvand, A. (2006). Timing of fungicide applications against anthracnose in sweet and sour cherry production in Norway. Crop Protection, 25(8), pp. 781-787. ISSN: 0261-2194 
Børve, J., Djønne ,R. \& Stensvand A. (2010). Colletotrichum acutatum occurs symptomatically on sweet cherry leaves. European Journal of Plant Pathology, 127(3), pp. 325-332. ISSN: 0929-1873

Frank, K.L., Kalkstein, L.S., Geils, B.W. \& Thistle, H.W. (2008). Synoptic climatology of the long-distance dispersal of white pine blister rust. I. Development of an upper level synoptic classification. International Journal of Biometeorology, 52(7), pp.641-652. ISSN: 0020-7128

Frazer, G.W., Wulder, M.A. \& Niemann, K.O. (2005). Simulation and quantification of the fine-scale spatial pattern and heterogeneity of forest canopy structure: A lacunarity-based method designed for analysis of continuous canopy heights. Forest Ecology and Management, 214(1-3), pp. 65-90. ISSN: 0378-1127

Garcia-Mozo, H., Gomez-Casero, M.T., Dominguez, E. \& Galan, C. (2007). Influence of pollen emission and weather-related factors on variations in holm-oak (Quercus ilex subsp. ballota) acorn production. Environmental and Experimental Botany, 61(1), pp. 35-40. ISSN: 0098-8472

Jacquemin, B., Lanki, T., Yli-Tuomi, T., Vallius, M., Hoek, G., Heinrich, J., Timonen, K. \& Pekkanen, J., (2009). Source category-specific PM(2.5) and urinary levels of Clara cell protein CC16. The ULTRA study. Inhalation Toxicology, 21(13), pp. 1068-1076. ISSN: 0895-8378

Lewi, PJ (2005). Spectral mapping, a personal and historical account of an adventure in multivariate data analysis. Chemometrics and Intelligent Laboratory Systems, 77(1-2), pp. 215-223. ISSN: 0169-7439

Lighthart, B., Shaffer, B.T., Frisch, A.S. \& Paterno, D. (2009). Atmospheric culturable bacteria associated with meteorological conditions at a summer-time site in the midWillamette Valley, Oregon. Aerobiologia, 25(4), pp. 285-295. ISSN: 0393-5965

Magyar D (1998) Adatok a Budakeszi-erdQǴmikroszkópikus gombáinak ismeretéhez. MSc, St. Steven University [Data to the Knowledge of the Microscopic Fungi in the Forests around Budakeszi]

Magyar D (2007) Aeromycological aspects of mycotechnology. In: Mycotechnology: Current Trends and future Prospects. (ed. M.K. Rai) I.K. International Publ. House, New Delhi: 226-263. ISBN: 9788189866082

Magyar, D., Eszeki, E.R., Oros, G., Szecsi, A., Kredics, L., Hatvani, L. \& Körmöczi, P. (2011). The air spora of an orchid greenhouse. Aerobiologia, 27(2), pp. 121-134. ISSN: 0393-5965

Mardia, K.V., Kent, J.T. \& Bibby, J.M. (1979). Multivariate Analysis, Academic Press, London, 213-254.

Mason E.W. (1937). Annotated account of fungi received at the Imperial Mycological Institute, List II, Fasc. 3., Kew, Surrey, IMI, pp . 69-99. ISSN 0027-5522 ; 3

Oros, G. \& Naár, Z. (2008). Környezetkímélő biocidek és alkalmazásuk. HPO 0800405

Oros, G., Vajna, L., Balázs, K., Fekete, Z., Naár, Z. \& Eszéki, E. (2010). Anthracnose and possibilities of the control with special regard to resident Glomerella population in sour cherry plantations of East Hungary. Agricultural Research, 39, pp. 12-17. ISSN 15871282

Oros, G., Naár, Z. \& Cserháti, T. (2011). Growth response of Trichoderma species to organic solvents. Molecular Informatics, 30(2-3):276-285. ISSN: 1868-1743

Parrado, Z.G., Barrera, R.M.V., Rodriguez, C.R.F., Maray, A.M.V., Romero, R.P., Fraile, R. \& Gonzalez, D.F. (2009). Alternative statistical methods for interpreting airborne Alder (Alnus glutimosa [L.] Gaertner) pollen concentrations. International Journal of Biometeorology, 53(1), pp. 1-9. ISSN: 0020-7128 
Quraishi, T.A., Schauer, J.J. \& Zhang, Y.X. (2009). Understanding sources of airborne water soluble metals in Lahore, Pakistan. Kuwait Journal of Science E Engineering, 36(1A), pp. 43-62. ISSN: 1024-8684

Pearson, K. (1901). On lines and planes of closest fit to systems of points in space. Philosophical Magazine, 6(2), pp. 559-572. ISSN: 1478-6435

Ribeiro, H., Cunha, M. \& Abreu, I. (2007). Improving early-season estimates of olive production using airborne pollen multi-sampling sites RID A-6708-2010 RID A6711-2010. Aerobiologia, 23(1), pp. 71-78. ISSN: 0393-5965

Ribeiro, H., Cunha, M. \& Abreu, I. (2008). Quantitative forecasting of olive yield in Northern Portugal using a bioclimatic model RID A-6708-2010 RID A-6711-2010. Aerobiologia, 24(3), pp. 141-150. ISSN: 0393-5965

Rungratanaubon T., Panich, N.\& Wangwongwattana, S. (2008). Characterization and source identification of trace metals inairborne particulates of Bangkok, Thailand. Annals of the New York Academy of Sciences, 1140, pp. 297-307. ISSN: 0077-8923

Sammon, J.W. (1969). A nonlinear mapping for data structure analysis, IEEE Transactions on Computers, 18, pp. 401-407. ISSN: 0018-9340

Schwarz, A., Wilcke, W., Kobza, J. \& Zech, W. (1999). Spatial distribution of soil heavy metal concentrations as indicator of pollution sources at Mount Krizna (Great Fatra, central Slovakia) RID A-1573-2008. Journal of Plant Nutrition and Soil Science, 162(4), pp. 421-428. ISSN: 1436-8730

Shah, M.H., Shaheen, N., Jaffar, M., Khalique, A, Tariq, S.R. \& Manzoor, S. (2006). Spatial variations in selected metal contents and particle size distribution in an urban and rural atmosphere of Islamabad, Pakistan. Journal of Environmental Management, 78(2), pp. 128-137. ISSN: 0301-4797

Shaheen, N., Shah, M.H. \& Jaffar, M. (2005). A study of airborne selected metals and particle size distribution in relation to climatic variables and their source identification. Water Air and Soil Pollution, 164(1-4), pp.275-294. ISSN: 0049-6979

Titseesang, T., Wood, T. \& Panich, N. (2008). Leaves of Orange Jasmine (Murraya paniculata) as Indicators of Airborne Heavy Metal in Bangkok, Thailand. Annals of The New York Academy of Sciences, 1140, pp. 282-289. ISSN: 0077-8923

Tokalioglu, S., Yilmaz, V. \& Kartal, S. (2010). An Assessment on Metal Sources by Multivariate Analysis and Speciation of Metals in Soil Samples Using the BCR Sequential Extraction Procedure. Clean-Soil Air Water, 38(8), pp. 713-718. ISSN: 1863-0650

Uno, Y., Prasher, S.O., Lacroix, R., Goel, P.K., Karimi, Y., Viau, A. \& Patel, R.M. (2005). Artificial neural networks to predict corn yield from Compact Airborne Spectrographic Imager data. Computers and Electronics in Agriculture, 47(2), pp. 149-161. ISSN: 0168-1699

Yang, C., Everitt, J.H. \& Bradford, J.M. (2004). Airborne hyperspectral imagery and yield monitor data for estimating grain sorghum yield variability. Transactions of The Asae, 47(3), pp. 915-924. ISSN: 0001-2351

You, X.Q., Senthilselvan, A., Cherry, N.M., Kim, H.M. \& Burstyn, I. (2008). Determinants of airborne concentrations of volatile organic compounds in rural areas of Western Canada. Journal of Exposure Science and Environmental Epidemiology, 18(2), pp. 117-128. ISSN: 1559-0631

Vasconcellos, P.C., Balasubramanian, R., Bruns, R.E., Sanchez-Ccoyllo, O. Andrade, M.F., Flues, M. (2007). Water-soluble ions and trace metals in airborne particles over urban areas of the state of Sauo Paulo, Brazil: Influences of local sources and long range transport RID C-2243-2011. Water Air and Soil Pollution, 186(1-4), pp. 63-73. ISSN: 0049-6979 


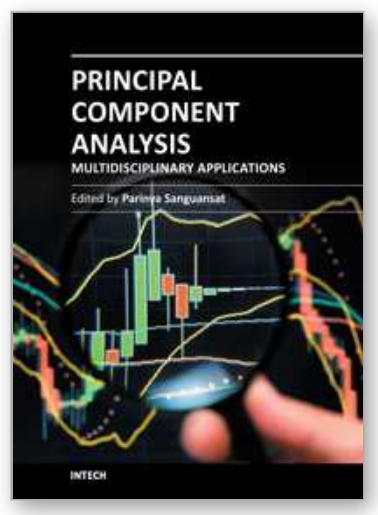

\author{
Principal Component Analysis - Multidisciplinary Applications \\ Edited by Dr. Parinya Sanguansat
}

ISBN 978-953-51-0129-1

Hard cover, 212 pages

Publisher InTech

Published online 29, February, 2012

Published in print edition February, 2012

This book is aimed at raising awareness of researchers, scientists and engineers on the benefits of Principal Component Analysis (PCA) in data analysis. In this book, the reader will find the applications of PCA in fields such as taxonomy, biology, pharmacy,finance, agriculture, ecology, health and architecture.

\title{
How to reference
}

In order to correctly reference this scholarly work, feel free to copy and paste the following:

Donát Magyar and Gyula Oros (2012). Application of the Principal Component Analysis to Disclose Factors Influencing on the Composition of Fungal Consortia Deteriorating Remained Fruit Stalks on Sour Cherry Trees, Principal Component Analysis - Multidisciplinary Applications, Dr. Parinya Sanguansat (Ed.), ISBN: 978953-51-0129-1, InTech, Available from: http://www.intechopen.com/books/principal-component-analysismultidisciplinary-applications/application-of-the-principal-component-analysis-to-disclose-factors-influencingon-the-composition-o

\section{INTECH}

open science | open minds

\section{InTech Europe}

University Campus STeP Ri

Slavka Krautzeka 83/A

51000 Rijeka, Croatia

Phone: +385 (51) 770447

Fax: +385 (51) 686166

www.intechopen.com

\section{InTech China}

Unit 405, Office Block, Hotel Equatorial Shanghai

No.65, Yan An Road (West), Shanghai, 200040, China

中国上海市延安西路65号上海国际贵都大饭店办公楼 405 单元

Phone: +86-21-62489820

Fax: $+86-21-62489821$ 
(C) 2012 The Author(s). Licensee IntechOpen. This is an open access article distributed under the terms of the Creative Commons Attribution 3.0 License, which permits unrestricted use, distribution, and reproduction in any medium, provided the original work is properly cited. 